Shaw, Tsen-Hwang 1936. The birds of Hopei Province, vol. 2. Peking: Zoologica Sinica Ser. B, Fan Mem. Inst. Biol.

Smythies, B. E. 1953. The birds of Burma. London: Oliver \& Boyd.

Smythies, B. E. 1960. The birds of Borneo. London: Oliver $\&$ Boyd.

StanFiELD, J. P. 1973. Aerial feeding by bulbuls. Ibis 115: 606 .

SwINhoE, R. 1863. The ornithology of Formosa, or Taiwan. Ibis 5: 250-311.

WhistleR, H. 1949. Popular handbook of Indian birds. London: Oliver \& Boyd.

3761 Park Avenue

SHELdON R. SEvERINGHaus

Coconut Grove, Fla. 33133, U.S.A.

2 March 1977

\title{
THE INFLUENCE OF AGE ON THE BREEDING BIOLOGY OF THE TREE SWALLOW IRIDOPROCNE BICOLOR
}

In certain bird species the age of the female has been shown to influence breeding performance, e.g., larids (Coulson \& White 1958, Davis 1975, Ryder 1975, Coulson \& Horobin 1976) and some European passerines (see Klomp 1970, for summary). Few comparable studies of North American passerines have explored this subject (recently, see Crawford 1977). Here I present such information for the Tree Swallow Iridoprocne bicolor.

The life history of this species was described by early workers (e.g., Chapman 1935), several of whom noted that yearling females retained a brownish, juvenile-like plumage unlike the bright blue-green plumage of older females and of all males (Low 1933, Kuerzi 1941). That this might reflect age-dependent differences in female breeding biology was considered only by Kuerzi (1941), but in no great detail. While he found that laying dates of females tended to be earlier in their second year of breeding than in their first, he did not find any apparent differences in reproductive efficiency between yearling and older females. In the following pages, however, I document significant variation between female Tree Swallows of different ages in a number of aspects of their breeding biology.

\section{METHODS}

This study was conducted from 1975-77 on Long Point, Ontario, Canada, a sandspit that extends $29 \mathrm{~km}$ from the northern shore of Lake Erie. A Tree Swallow nest-box colony has been established there in semi-flooded dune-grass habitat for approximately seven years. Staff of the Long Point Bird Observatory (LPBO) maintain nesting records for the colony and supervise annual ringing of nestlings and breeding females (lack of an efficient trapping device prevented capture of more than a small proportion of males until 1976).

In 1975 and 1976, I made daily visits to nest-boxes during the laying period to determine exact laying dates and clutch sizes. On the date of laying, each egg was marked individually and weighed using a Pesola spring balance accurate to $0.1 \mathrm{~g}$. Subsequent visits to nest-boxes were timed to determine exact hatching dates. Nestlings were ringed 12 days after hatching with U.S. Fish \& Wildlife Service aluminum bands, and their progress was followed until fledging at 18-20 days.

About six days after their chicks had hatched, females were captured on the nest at night while brooding and were weighed using a Pesola spring balance accurate to $0.5 \mathrm{~g}$. Captures were performed c. $02.00 \mathrm{hrs}$ in 1975 and $c .11 .00 \mathrm{hrs}$ in 1976, and consequently data have been analysed separately for the two years. Some females already ringed could be aged exactly; those not previously ringed could be classed as 'yearling' or 'older' according to plumage. No nest desertions by females resulted from capture at night. In 
1976 , by means of a mechanical device affixed to the nest-boxes, it was also possible to capture most of the breeding males as they fed nestlings. The device was essentially a 'mousetrap' with netting, tripped automatically when a bird entered a nest-box.

Metal shields were placed on the nest-box poles in order to exclude predators. While the Tree Swallow is thought to be single-brooded, replacement nestings sometimes occur if clutches are disturbed or destroyed early in the season (Kuerzi 1941). Thus I excluded from analyses of hatching and fledging success a number of nests disturbed by predation early in the season of 1975 , although these nests could still be used in other analyses. I also excluded completely from analysis nine apparent re-nestings in 1975 . I say 'apparent' because the prior attempts were destroyed before the females could be identified; thus I could not determine if these instances were actually replacement nestings or were first attempts by other females.

A series of brood-size experiments were performed in 1976 (De Steven, in prep.); only 'control' nests are used here for analysis of 'normal' fledging success for that year. These 'controls' differed from the 1975 nests in that I replaced any hatching losses with chicks from other nests, so that in all nests brood size was invariably equal to the original clutch size. Only chicks that hatched on the same date as chicks of the recipient brood were used for replacement, and transfers were performed within one or two days of hatching. Transfer did not appear to affect nestling survival; all nestling mortality in 'control' broods occurred in nests with no hatching losses.

Table 1

Breeding statistics (means and standard errors) of yearling and older female Tree Swallows

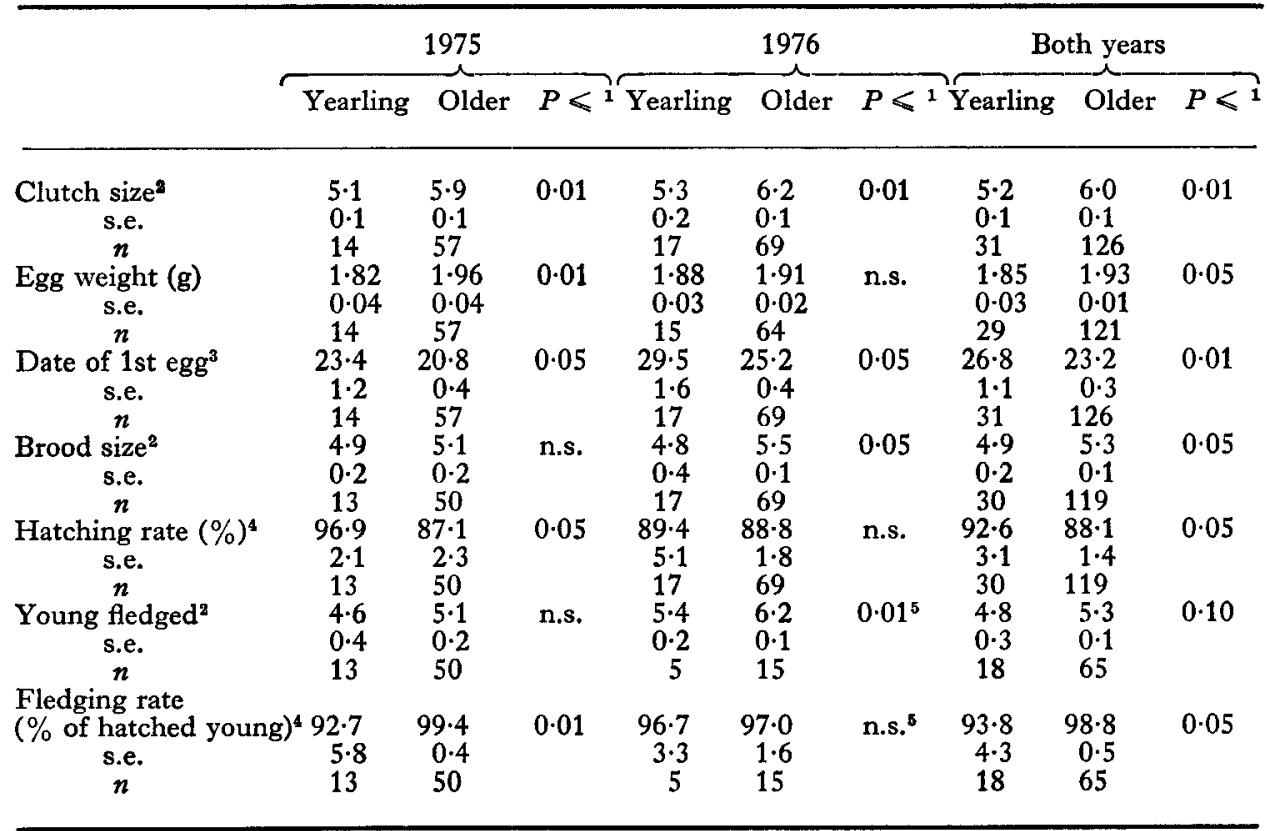

Notes: ${ }^{1}$ Probabilities are for Student's $t$-test, except where otherwise noted. n.s. denotes not statistically significant.

${ }^{2} t$ statistic used here is an approximation to the randomization test for large sample sizes (Siegel 1956).

3 Based on counting 1st May as ' 1 ', etc. Student's $t$-test performed on log-transformed data. $\chi^{2}$ test.

5 'Control' broods only. See Methods section for explanation. 
RESULTS

A summary of breeding statistics (mean \pm s.e.) of female Tree Swallows is presented in Table 1.

Clutch size normally ranges from three to seven (rarely, three to eight), and yearling females lay significantly smaller clutches than older females (Table 1). Clutch size also declines significantly with the season (Fig. 1). This seasonal decline reflects in part the later laying dates of yearling females as compared to older females (Table 1). However, a direct relationship between clutch size and season is also suggested by the significant (with one exception) negative correlation of these two variables within each female age category (Table 2).

TABLE 2

Correlation between clutch size and date of laying for yearling and older female Tree Swallows in 1975 and $1976^{1}$

\begin{tabular}{lcccc}
\hline & 1975 & $n$ & 1976 & $n$ \\
\hline Yearling females & -0.34 & 14 & $-0.50^{*}$ & 15 \\
Older females & $-0.27 *$ & 57 & $-0.29 *$ & 63 \\
\hline
\end{tabular}

Note: ${ }^{1}$ Spearman's rank correlation. "denotes $P \leqslant 0 \cdot 05$

Females tended to advance (relative to the mean) their date of laying in their second year of breeding more often (four of five instances) than did older females in the second of two successive years (eight of 18 instances) (cf. Kuerzi 1941).

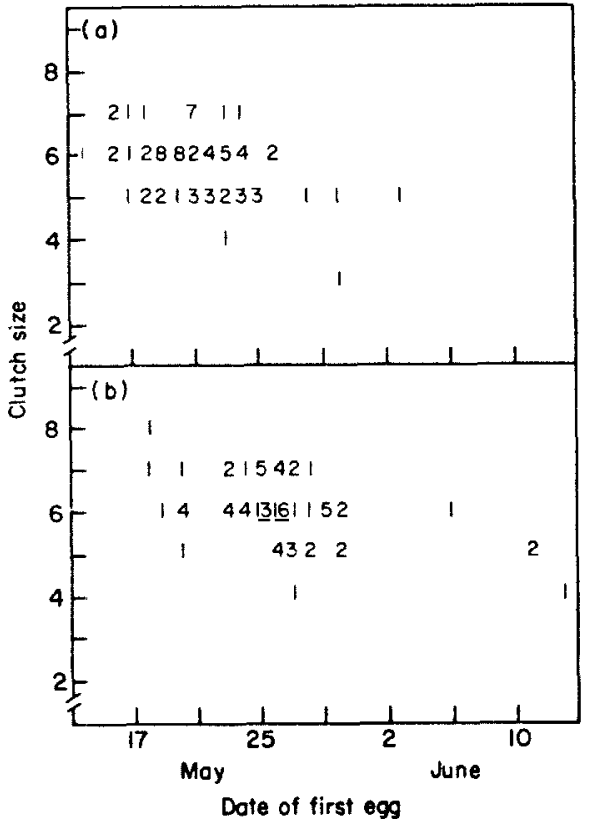

FIgure 1. Seasonal variation in clutch size of Tree Swallows in (a) 1975 and (b) 1976. Probabilities are for Spearman's rank correlation. (a) $r_{\mathrm{B}}=-0.35, P<0.01, n=71$. (b) $r_{\mathrm{B}}=-0.43, P<$ $0.01, n=86$. 


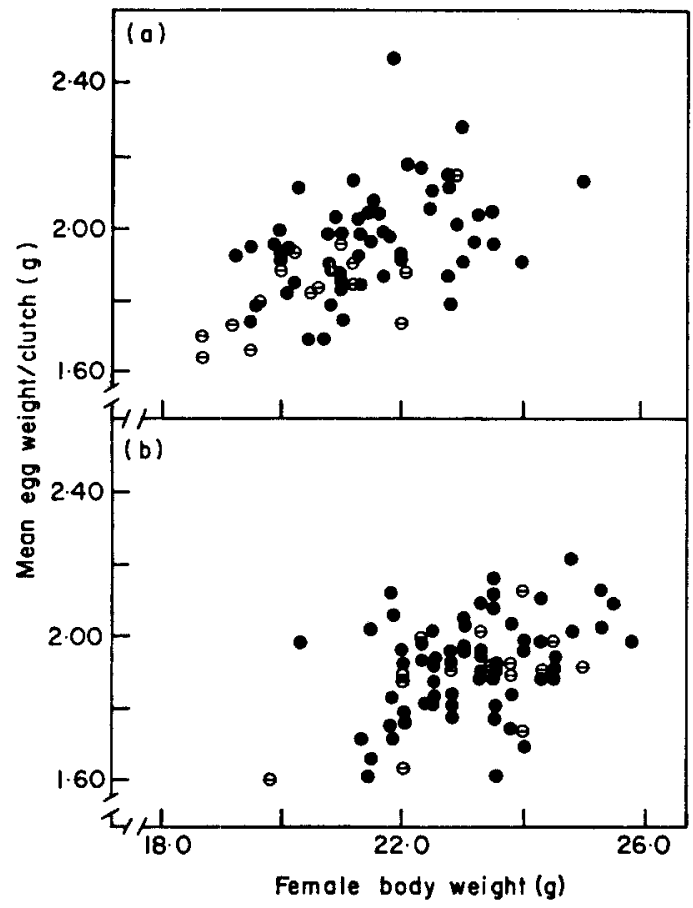

FIgURE 2. Relationship between body weight of female Tree Swallows and the average egg weight of their clutches. Probabilities are for Pearson's product-moment correlation. (a) 1975, $r=0.52, P<0.01, n=71$. (b) $1976, r=0.40, P<0.01, n=78$. $\ominus$, yearling females; older females.

Egg weights ranged from 1.40 to $2.55 \mathrm{~g}$, and $69 \%$ (in 1975) to $72 \%$ (in 1976) of this variation is accounted for by between-clutch differences (anova, $P<0.001$ ). Individual females lay eggs of similar weight in successive years (paired $t=0 \cdot 0, P>0 \cdot 10, n=23$ ). In addition, egg weight is significantly correlated with female body weight regardless of age (Fig. 2). It should be noted that lighter body weight and egg weight are not necessary results of smaller size, since body weight and wing length were not significantly correlated (in 1975, $r=0 \cdot 16$, n.s., $n=71$; in 1976, $r=0 \cdot 17$, n.s., $n=78$ ). Egg weight and wing length were similarly uncorrelated.

Yearlings tend to lay lighter eggs than older females; this difference was significant in 1975 but not in 1976 (Table 1). Body weights reflect this trend, with yearlings averaging significantly lighter in weight only in $1975(t=2.56, P<0.01, n=71)$. Yearlings also tend to be smaller (as measured by wing length) than older females, but this difference was not quite significant in either year $(t$ test, $0.05<P<0.10)$. The lighter egg weights of yearlings were not related to their later laying dates, since there was no correlation between egg weight and date of laying (in 1975, $r=0.07$, n.s., $n=71$; in 1976, $r=0.05$, n.s., $n=78$ ).

It was determined for a sample of eggs that I directly observed hatching that heavier eggs produce heavier hatchlings $\left(R^{2}=0.55, P<0.01, n=10\right)$, but neither hatching success nor fledging success was significantly correlated with egg weight in either year.

Yearling females appear to have a higher hatching rate than older females, although not significantly in 1976. This resulted in the average brood size of yearlings being comparable to that of older females in 1975 , but not in 1976 when older females averaged larger broods in keeping with their larger average clutch size (Table 1). 
Older females had higher fledging rates (calculated as \% of hatched young) and also reared more young, on average, reflecting their larger initial clutch size (Table 1). That older females will tend to fledge more young is also illustrated by the consistently greater productivity of larger brood sizes (Table 3 ). The contribution of male feeding behaviour could not be assessed in this study, but presumably could influence nestling survival considerably.

TABLE 3

Productivity (mean \pm s.e.) of Tree Swallow broods

\begin{tabular}{|c|c|c|c|c|}
\hline \multirow[b]{2}{*}{ Brood size } & \multicolumn{4}{|c|}{ No. of young fledged } \\
\hline & 1975 & $n$ & $1976^{1}$ & $n$ \\
\hline $\begin{array}{l}3 \\
4 \\
5 \\
6 \\
7\end{array}$ & $\begin{array}{c}3.0 \\
3.8 \pm 0.2 \\
4.9 \pm 0.1 \\
5.9 \pm 0.1 \\
6.7 \pm 0.3\end{array}$ & $\begin{array}{r}2 \\
15 \\
21 \\
21 \\
3\end{array}$ & $\begin{array}{c}\text { 二 } \\
5 \cdot 0 \\
5 \cdot 9 \pm 0 \cdot 1 \\
6 \cdot 6 \pm 0 \cdot 2\end{array}$ & $\begin{array}{r}2 \\
13 \\
5\end{array}$ \\
\hline
\end{tabular}

Note: ${ }^{1}$ 'Control' broods only. See Methods section for explanation.

Fledging success does not necessarily indicate long-term breeding success, which is measured by the number of young that survive to breed. The Tree Swallow is migratory, and the return rate of fledged young to the breeding site in subsequent years is in the order of $5 \%$, in contrast to return rates ranging from $30-40 \%$ for adults. The lower return rate for juveniles has been attributed both to high post-fledging and winter mortalities and to wide dispersal to other areas to breed (Chapman 1935). Assuming that every fledgling is equally likely to return to the breeding site if it has not suffered mortality, such returns can be treated as reflections of survival patterns. Table 4 contains data for 1975 fledglings of both sexes that returned to the colony in either 1976 or 1977. Young of late broods tend to return less often, although not significantly $\left(\chi^{2}=2 \cdot 39, \mathrm{df}=2\right.$, $\mathrm{n.s.})$. A lower return rate for young of yearlings is also suggested $\left(\chi^{2}=0 \cdot 60, \mathrm{df}=1\right.$, n.s.), but yearlings also tend to breed later. These few data do not permit separation of an effect of age of the parent from that of hatching date. Finally, there is no consistent trend of survival in relation to brood size $\left(\chi^{2}=1 \cdot 13, \mathrm{df}=3, \mathrm{n} . \mathrm{s}\right.$. $)$.

The sample of 'control' broods in 1976 is too small for analysis of fledgling returns; a complete analysis for all broods fledged in the 1976 experiments (cf. Methods) will be presented elsewhere (De Steven, in prep.).

\section{DISCUSSION}

These findings are consistent with others that have demonstrated improvement in breeding performance with age, and the phenomenon may prove to be general. Presumably this involves an increase in some aspect of parental experience. The aerial foraging habit of the Tree Swallow would seem to require considerable skill, and it may be that yearlings are not as efficient at foraging as are older individuals and therefore cannot rear as many young. Such an explanation has been suggested for other species (Ainley \& Schlatter 1972, Perrins \& Moss 1974, Bryant 1975) and is supported by studies documenting variations in foraging ability with age (Orians 1969, Recher \& Recher 1969, Dunn 1972). Additionally, Källander (1974) has shown for the Great Tit Parus major that provision of extra food during the laying period advanced the laying dates of yearling females to a greater extent than those of older females. That less experienced individuals 
TABLE 4

Returns in 1976 or 1977 of Tree Swallows fledged in 1975, according to date of hatching, age of female parent, and brood size

\begin{tabular}{|c|c|c|c|c|c|}
\hline & $\begin{array}{l}\text { No. of young } \\
\text { fledged }\end{array}$ & $\begin{array}{l}\text { No. of } \\
\text { broods }\end{array}$ & $\begin{array}{c}\text { No. of young } \\
\text { returned }\end{array}$ & $\begin{array}{l}\% \text { returned of } \\
\text { young fledged }\end{array}$ & $\begin{array}{l}\text { No. returned } \\
\text { per brood }\end{array}$ \\
\hline $\begin{array}{c}\text { Date of hatchin } \\
\text { June } 3-9 \\
\text { June } 10-16 \\
\text { June } 17-24\end{array}$ & $\begin{array}{r}186 \\
166 \\
59\end{array}$ & $\begin{array}{l}38 \\
34 \\
12\end{array}$ & $\begin{array}{r}18 \\
13 \\
2\end{array}$ & $\begin{array}{l}9 \cdot 7 \\
7 \cdot 8 \\
3 \cdot 4\end{array}$ & $\begin{array}{l}0 \cdot 47 \\
0 \cdot 38 \\
0 \cdot 17\end{array}$ \\
\hline $\begin{array}{l}\text { Age of female p } \\
\text { Yearling } \\
\text { Older }\end{array}$ & $\begin{array}{r} \\
\text { ent }^{1} \\
68 \\
331\end{array}$ & $\begin{array}{l}15 \\
67\end{array}$ & $\begin{array}{r}4 \\
29\end{array}$ & $\begin{array}{l}5.9 \\
8.8\end{array}$ & $\begin{array}{l}0.27 \\
0.43\end{array}$ \\
\hline $\begin{array}{c}\text { Brood size } \\
3 \\
4 \\
5 \\
6 \\
7\end{array}$ & $\begin{array}{r}15 \\
77 \\
142 \\
149 \\
27\end{array}$ & $\begin{array}{r}5 \\
20 \\
29 \\
25 \\
4\end{array}$ & $\begin{array}{r}1 \\
6 \\
10 \\
14 \\
2\end{array}$ & $\begin{array}{l}6 \cdot 7 \\
7 \cdot 8 \\
7 \cdot 0 \\
9 \cdot 4 \\
7 \cdot 4\end{array}$ & $\begin{array}{l}0.20 \\
0.30 \\
0.34 \\
0.56 \\
0.50\end{array}$ \\
\hline
\end{tabular}

Note: I Females of two broods were not identified and have been omitted from the age analysis.

attempt to breed at all may be due to the importance of early reproduction for relatively short-lived species (Cole 1954, Gadgil \& Bossert 1970, Perrins \& Moss 1974). Annual losses of adult Tree Swallows from the colony averaged about $50 \%$ for the period of this study. Mortality may account for most of these losses, since females will tend to return to the same breeding site if they have previously bred there successfully (Bradstreet 1969).

The variation in egg weight and the correlation of egg weight with body weight are of interest. Among free-living species, a similar correlation has been found for the Great Tit (Jones 1970) and the Wood-pigeon Columba palumbus (Murton, Westwood \& Isaacson 1974). This would appear to be related to the ability to gather and retain resources; body weight has been shown to be a good indicator of the amount of fat reserves (Murton $e t$ al. 1974), thus its variation may be reflective of different abilities to forage effectively (Jones \& Ward 1976). This is consistent with the suggestion that yearling Tree Swallows are more inexperienced foragers, since they tend to be lighter in weight and lay lighter eggs. The variation in egg weight did not directly influence breeding success, however. Although the larger hatching weight resulting from larger egg weight may confer an initial advantage for nestling survival under some circumstances (Schifferli 1973), subsequent parental feeding behaviour may either compensate for (O'Connor 1975) or accentuate (Parsons 1970, Howe 1976) the initial differences in weight.

The largest Tree Swallow broods were most productive (cf. Paynter 1954), and there was no apparent influence of brood size on fledgling survival. Paynter (1954) has discussed variations in breeding success in this species and suggests that higher mortality in large broods may not be observed in areas of abundant food supply. This would seem to be the case for the Tree Swallows at Long Point, where there are a number of both temporary and permanent ponds that provide a rich source of emerging aerial insects.

The data do indicate that young from late broods suffer higher mortality. An alternative explanation is greater dispersal of late-hatched young away from the breeding site, as has been shown for the Great Tit (Dhondt \& Huble 1968). This may be less likely for a migratory species such as the Tree Swallow in which all individuals leave the breeding area and then return each year. In late broods, lowered survival has been attributed to 
deteriorating food supplies as the season progresses, although the inexperience of latebreeding adults may also be contributory (Perrins 1970). Hussell (1972) offered a third possible explanation in the case of some arctic passerines whose seasonal decline in clutch size was not paralleled by a seasonal decline in food supply. In those species, young from late broods may not have enough time to moult and accumulate fat reserves before migrating south. At Long Point, Swallows Hirundo rustica extend their breeding period beyond that of the Tree Swallow to include second broods. This at least suggests that there is no rapid decline in aerial insect abundance immediately after Tree Swallow young are fledged, although differences in food selectivity between the two species could be important. However, the Tree Swallow is one of the few North American swallows that completes its moult before arriving at its wintering areas, and juveniles appear to begin moult later than do adults (Stone 1896, Dwight 1900, Forbush 1929). Late-hatched young may have less time available to become proficient feeders and both complete the moult and gather sufficient energy reserves during migration.

My appreciation is extended to the Long Point Company for permission to conduct this study on Long Point, and to the Long Point Bird Observatory for use of facilities. I thank LPBO Director D. J. T. Hussell for invaluable assistance in numerous regards. D. Bird, G. Miller, R. Purtill and especially S. Freyburger provided aid in the field. D. Bryant, E. H. Dunn, H. Howe, D. Hussell, R. Payne and D. Tinkle made helpful comments on the manuscript. Partial support for this study was provided in 1976 by a Frank M. Chapman Grant from the American Museum of Natural History.

\section{REFERENCES}

Ainley, D. G. \& Schlatter, R. P. 1972. Chick raising ability in Adélie Penguins. Auk 89: 559-566. Bradstreet, M. S. W. 1969. Consecutive nesting of female swallows at Long Point, Ontario. Ontario Bird-Banding 5: 68-71.

BRyant, D. M. 1975. Breeding biology of House Martins Delichon urbica in relation to aerial insect abundance. Ibis 117: 180-216.

Chapman, L. B. 1935. Studies of a Tree Swallow colony. Bird-Banding 6:45-57.

COLE, L. C. 1954. The population consequences of life history phenomena. Quart. Rev. Biol. 29: $103-137$.

Coulson, J. C. \& Horobin, J. 1976. The influence of age on the breeding biology and survival of the Arctic Tern Sterna paradiseaea. J. Zool., Lond. 178: 247-260.

Coulson, J. C. \& WHITE, E. 1958. The effect of age on the breeding biology of the Kittiwake Rissa tridactyla. Ibis 100: 40-51.

CRAwFord, R. D. 1977. Breeding biology of year-old and older female Red-winged and Yellowheaded Blackbirds. Wilson Bull. 89: 73-80.

Davis, J. W. F. 1975. Age, egg-size, and breeding success in the Herring Gull Larus argentatus. Ibis $117: 460-473$.

Dhondt, A. A. \& Huble, J. 1968. Fledging-date and sex in relation to dispersal in young Great Tits. Bird Study 15: 127-134.

DunN, E. K. 1972. Effect of age on the fishing ability of Sandwich Terns Sterna sandvicensis. Ibis 114: 360-366.

Dwight, J, 1900. The sequence of plumages and moults of the passerine birds of New York. Ann. New York Acad. Sci. 13: 73-360.

ForbusH, E. H. 1929. Birds of Massachusetts and other New England states. Norwood, Mass.: Norwood Press.

Gadgil, M. \& Bossert, W. H. 1970. Life historical consequences of natural selection. Am. Nat. 104: 1-24.

Howe, H. F. 1976. Egg size, hatching asynchrony, sex, and brood reduction in the Common Grackle. Ecology 57: 1195-1207.

HuSSELL, D. J. T. 1972. Factors affecting clutch size in arctic passerines. Ecol. Monogr. 42: 317-364.

JONES, P. 1970. Food as a proximate factor regulating the breeding season of the Great Tit (Parus major). Proc. 15 Intl. Ornithol. Congr.: 657-658.

JONES, P. J. \& WARD, P. 1976. The level of reserve protein as the proximate factor controlling the timing of breeding and clutch-size in the Red-billed Quelea Quelea quelea. Ibis 118: 547-574.

KäLLANDER, H. 1974. Advancement of laying of Great Tits by the provision of food. Ibis 116: 365-367.

KLOMP, H. 1970. The determination of clutch-size in birds: a review. Ardea 58: 1-124.

Kuerzi, R. G. 1941. Life-history studies of the Tree Swallow. Proc. Linn. Soc. New York 52-53: 1-52.

Low, S. H. 1933. Further notes on the nesting of the Tree Swallows. Bird-Banding 4: 76-87.

Murton, R. K., Westwood, N. J. \& Isaacson, A. J. 1974. Factors affecting egg-weight, bodyweight, and moult of the Woodpigeon Columba palumbus. Ibis 117: 52-73. 
O'ConNor, R. J. 1975. An adaptation for early growth in tits, Parus spp. Ibis 117: 523-526.

OrIans, G. H. 1969. Age and hunting success in the Brown Pelican (Pelecanus occidentalis). Anim. Behav. 17: 316-319.

Parsons, J. 1970. Relationship between egg size and post-hatching chick mortality in the Herring Gull (Larus argentatus). Nature, Lond. 228: 1221-1222.

PAYNTER, R. A. 1954. Interrelationships between clutch-size, brood-size, prefledging survival, and weight in Kent Island Tree Swallows. Bird-Banding 25: 35-58, 102-110, 136-148.

Perrins, C. M. 1970. The timing of birds' breeding seasons, Ibis 112: 242-255.

Perrins, C. M. \& Moss, D. 1974. Survival of young Great Tits in relation to age of female parent. Ibis $116: 220-224$.

Recher, H. F. \& RECHER, J. A. 1969. Comparative foraging efficiency of adult and immature Little Blue Herons (Florida caerulea). Anim. Behav. 17: 320-322.

RYDER, J. P. 1975. Egg-laying, egg size, and success in relation to immature-mature plumage of Ring-billed Gulls. Wilson Bull. 87: 534-542.

SCHIFFERL, L. 1973. The effect of egg weight on the subsequent growth of nestling Great Tits Parus major. Ibis 115: 549-558.

SiEgex, S. 1956. Nonparametric statistics. New York: McGraw-Hill.

SrONE, W. 1896 . The molting of birds with special reference to the plumages of the smaller land birds of eastern North America. Proc. Acad. Nat. Sci. Philadelphia 1896: 108-167.

Museum of Zoology,

Diane De Steven

University of Michigan,

Ann Arbor, MI 48109,

U.S.A.

2 May 1977

\section{STRUCTURAL ASPECTS OF THE SPECULUM OF MALLARD ANAS PLATYRHYNCHOS}

Feathers show immense structural diversity but are composed almost exclusively of keratins. These proteins are unique in several respects and consist of a relatively large number of similar, but not identical subunits, encoded by a family of closely related structural genes. The shape and other functional properties of feathers are determined by an unknown number of regulatory genes. (For review, see Brush 1978). Chemically, feather keratins share common characteristics with those of the beak (Frankel \& Gillespie 1976) and scales (Walker \& Bridgen 1976).

Despite a relatively advanced understanding of the chemical nature (O'Donnell \& Inglis 1974) and crystalline structure of the feather keratin monomer (Fraser \& MacRae 1976), we have little insight into the relationship of molecular organization with morphological diversity. In this study, I attempted to correlate the protein heterogeneity of the fine structure of the Mallard Anas platyrhynchos speculum with the molecular and functional organization at several levels.

\section{MATERIALS AND METHODS}

Wing feathers from several adult, male Mallards were solubilized, and the S-carboxymethyl derivatives (SCM-FKM) prepared (Brush 1976). Similar preparations were made of the shaft (rachis) and separately of the barbs of the vane on both sides of the speculum. The inner, or non-iridescent side served as a control for the iridescent portion. Samples were dialysed and lyophilized.

The SCM-FKM preparations made up to $40 \mathrm{mg} / \mathrm{ml}$ in the appropriate buffer were compared by polyacrylamide gel electrophoresis (PAGE) in Tris-glycine buffer ( $\mathrm{pH} \mathrm{8.6)}$ and by isoelectric focusing (IEF) on $7 \%$ polyacrylamide plates in a range of $\mathrm{pH} 4-6.5$. Gels were stained with Amino black. IEF slabs were soaked in $10 \%$ TCA to make the protein bands visible. 